\title{
Assessment of Genotype $\times$ Environment Interaction of Safflower (Carthamus tinctorius L.) Genotypes by Parametric and Non-Parametric Methods
}

\author{
İlhan Subaşı, Dilek Başalma
}

\section{ABSTRACT}

\begin{abstract}
Genotype-environment interaction is a significant factor for finding and selecting stable and productive varieties in safflower breeding programs. This study was conducted at three locations over two years (2016-2017) to determine the extent of genotype by environment (GE) interaction in seed and oil yield. 20 safflower lines and cultivars were evaluated in terms of stability in 3 environments. Considering the stability and performance, the most suitable genotypes were determined as Remzibey-05 and Genotype-125 in seed yield, Genotype-8 and Genotype-155 in oil yield.
\end{abstract}

In terms of stability and performances of genotypes, the environment of Ikizce 2017 (E4) was prominent. Correlation analysis among parametric and nonparametric features was given only for seed yield. The following stability parameters were calculated: the coefficient of variation $(\mathrm{CV})$, regression constant $\left(a_{i}\right)$, regression coefficient $\left(b_{i}\right)$, mean deviation squares from regression $\left(S^{2} d_{i}\right)$, coefficient of determination $\left(R_{i}^{2}\right)$, stability variance $\left(\sigma_{i}^{2}\right)$, ecovalance value $\left(\mathrm{W}_{\mathrm{i}}\right)$, stability index $\left(\mathrm{P}_{\mathrm{i}}\right)$ and as nonparametric stability measures $S_{i}(1)$ and $S_{i}(2)$ values. This analysis indicated that seed yield was significantly positively correlated only with $P_{i}(P<0.01)$. CV showed a positively significant correlation with $a_{i} . S^{2} d_{i}$ and $r_{i}^{2}$ had a positive association with $R_{i}^{2}, \sigma_{i}^{2}, W_{i}, P_{i}, S_{i}(1), S_{i}(2)$, and between each other.

Keywords: Safflower, Carthamus tinctorius L., genotyp x environment interaction, stability.

\section{INTRODUCTION}

Safflower is an annual, self-pollinated and diploid $(2 \mathrm{n}=$ 24) plant that has been used in the fields of oil, paint, textile, and medicine since ancient times [1], [2]. The crossfertilization rate is less than $10 \%$ [3]. Distribution of the wild species in Turkey, C. dentatus (Forssk.) Vahl., C. lanatus L., C. glaucus M.Bieb., and C. tenuis (Boiss. \& Blanche) Bornm., that are (4 types) Atractylis section and C. persicus Desf. ex Willd., that belongs to the Carthamus section [4]. Carthamus tinctorius is the only cultivated species of this genus that is grown in more than 20 countries. The optimum growing conditions for safflower are well-drained soils with hot and dry climates in early spring. The growing period of the safflower takes 17-20 weeks counting on environmental conditions [5]. Safflower-cereal rotations provide to benefit from fertilizers below the root depth of cereals. During the rosette period, the stem does not grow, but long taproots can grow up to 2-3 m deep (2-3 weeks). Safflower can be included in the cold-tolerant plant group, however, it cannot compete with weeds [6]. Safflower plants have between 0.5-1.8 m plant height [5]. The size and shape of the leaves differ among the varieties. It can be linear, lanceolate, oval, and ovum [7]. Since safflower has root tips that facilitate water intake even in dry environments, it can grow in arid places. In the past, the plant was firstly grown for its flowers which were widely used as a dye, tea and food additive. At present, it is also used for medical purposes in some parts of the World [8].

Phenotypic stability, yield stability, and adaptation terms are used in quite different concepts. Therefore, Becker and Leon [9] reported that Dorst uses the phrase "Adaptation has a great adaptation". Lin et al. [10] stated that scientists define adaptation depending on how they want to look at the problem. Depending on the target and the character taken into account, the concept of adaptation has been given the meaning of the concept of dynamic balance [9]. Contrary to the static concept, with steady performance of stable genotype, adaptation means a predictable response of dynamic concept. And, it can also be defined as dynamic stability [11].

Due to the regional variations in soil characteristics and climate conditions of Turkey, it is required to develop suitable varieties for each region, and adaptation of these varieties needs to be proven.

The main goal of a breeding program is to develop varieties with high adaptation capacity by improving the stability and yield of genotypes in many environments and regions.

It is more economical and feasible to find genotypes that are not affected much by different ecologic regions in terms of performance. Therefore, stability is an important parameter in developing cultivars. Stability statistics can provide different results according to different methods. This study evaluated the stability differences in Safflower genotypes 
with parametric and nonparametric stability parameters.

\section{MATERIALS AND MethodS}

The present study was conducted using agro-morphologic data from 20 safflower genotypes tested in 3 environments (year x location combinations during 2016-2017) under unirrigated.

conditions. The characteristics of the trial locations are presented in Table 1. Three locations were used for trials in the Black Sea region (Bolu: $40^{\circ} 43^{-} 23^{\prime \prime} \mathrm{N} ; 31^{\circ} 30^{-} 45^{\prime \prime}$ E), and Central Anatolian region (Yenimahalle: $39^{\circ} 57^{\prime} 19^{\prime \prime}$ $\mathrm{N} ; 32^{\circ} 48^{-} 46^{\prime \prime} \mathrm{E}$ and Gölbaşı: $39^{\circ} 36^{-} 53^{\prime \prime} \mathrm{N} ; 32^{\circ} 40^{-}$ $39^{\prime \prime}$ E) in Turkey. Trials were performed for 2 years. Genotypes, which were selected USDA accessions and local genotypes, were attained from Central Research Institute for Field Crops breeding program. The names/codes and origins of these genotypes are given in Table 1 .

For both trial years, the climate values of the locations were compatible with the long-term averages (LTA) (Table 2). Soil cross-section samples were taken from $0-20 \mathrm{~cm}$ and $20-40 \mathrm{~cm}$ depths at three different points of the research area and analyzed (Table 3 ).

The soil of İkizce and Yenimahalle locations is clayey loam and they have a high potassium ratio and poor organic matter content. On the other hand, the soil from Bolu location has a clayey texture and has relatively low potassium content (Table 3). Despite the salt problem, the soils from all locations have alkaline character and some useful phosphorus content (Table 3). Diammonium phosphate (DAP) and ammonium nitrate $\left(\mathrm{NH}_{4} \mathrm{NO}_{3}\right)$ fertilizers were applied together at sowing. The amount of fertilizer applied was calculated as $15 \mathrm{~kg} \mathrm{da}^{-1}$ pure nitrogen and $6 \mathrm{~kg} \mathrm{da}^{-1}$ pure phosphorus [12]. Each three parcel plots had a length of $6 \mathrm{~m}$ and were 6 rows per parcel. The planting distance between the rows was $25 \mathrm{~cm}$ and $3 \mathrm{~kg} \mathrm{da}^{-1}$ seed was used.

For oil and protein analyses, the homogeneous sample taken from the safflower seeds, which were obtained from each plot, was ground. The crude oil content of samples was determined as a weight/weight percentage (w/w \%). Analyzes were performed in the Field Crops Central Research Institute, Oilseed Plants Unit Laboratory with the Soxhlet extractor via solvent (hexane) extraction (Soxtherm 2000 automatic, C. Gerhardt GmbH \& Co. KG, Königswinter, Germany) using the method reported by Bertrand and Brühl [13].

The protein ratio of the homogeneous safflower seed samples taken each plot was detected by Dumas method (Velp Scientifica NDA-701) in the Field Research Center Quality and Technology Laboratory (according to the method of AOAC 992.23: Crude Protein in Cereal Grains and Oilseeds) [14], [15]. The nitrogen-to-protein conversion factor was used as 5.3 in the calculation of protein content.

Variance analyses were performed using JMP 11 (SAS Institute, Cary, NC, USA). In the preliminary statistical analysis, the year was found as an important factor in all locations. Therefore, each location of the experiments was accepted as a different environment in both 2016 and 2017 years. In statistical analysis, six environments data [Bolu 2016 (E1), Bolu 2017 (E2), İkizce 2016 (E3) İkizce 2017 (E4), Yenimahalle 2016 (E5), Yenimahalle 2017 (E6)] were used.

TABLE 1: SAFFLOWER GENOTYPES (PURE LINE AND VARIETY) AND ORIGINS USED IN MULTI-ENVIRONMENT SAFFLOWER TRIALS

\begin{tabular}{ccc}
\hline Line/Variety & PI Code of origin & Origin \\
\hline 8 & 304593 & Afghanistan \\
10 & 304593 & Afghanistan \\
56 & - & Turkey \\
75 & Cart-104 & Canada \\
76 & Cart-104 & Canada \\
83 & 560167 & Idaho, U.S.A \\
114 & 388908 & Iran \\
117 & 405985 & Iran \\
125 & 572434 & California, U.S.A \\
133 & Bd-98.1 & U.S.A \\
135 & 537712 & Arizona, U.S.A \\
143 & 525458 & Montana, U.S.A \\
155 & 537701 & Idaho, U.S.A \\
163 & 568816 & China \\
61 & L.C P-77 & Mexico \\
Dinçer & - & Turkey \\
Remzibey & - & Turkey \\
Balc1 & - & Turkey \\
Linas & - & Turkey \\
Olas & - & Turkey \\
\hline
\end{tabular}

The ideal test environment should have a larger PC1 (expressing the main genotypic effect) score and a smaller absolute PC2 (more representing the effect of the whole environment). Although it is not an ideal environment, it can be used as a reference in multiple environmental efficiency trials [16]. An environment, which is closer to the ideal environment, is defined as a better environment. Circles were created to better understand the closeness of the environment to the ideal environment. Ranges of genotypes are the most important information for the selection in the breeding and test programs [17]. Therefore, the estimation of phenotypic stability using only this ranking information appears to be an appropriate approach [18]. The following stability parameters were calculated: the coefficient of variation $(\mathrm{CV})$, regression constant (a), regression coefficient $\left(b_{i}\right)$, mean deviation squares from regression $\left(S^{2} d_{i}\right)$, coefficient of determination $\left(\mathrm{R}_{\mathrm{i}}^{2}\right)$, stability variance $\left(\sigma_{\mathrm{i}}^{2}\right)$ (developed by Shukla 1972) [19], ecovalance value $\left(\mathrm{W}_{\mathrm{i}}\right)$, stability index $\left(\mathrm{P}_{\mathrm{i}}\right)$ and nonparametric stability measures $S_{i}(1)$ and $S_{i}(2)$ values.

In this study, stability and adaptation analyzes were analyzed with the GEA-R (Genotype $x$ Environment Analysis with $\mathrm{R}$ for Windows) statistical program, developed by CIMMYT (International Maize and Wheat Improvement Center). Both programs were used in tables and figures related to stability and adaptation. 
TABLE 2: SOME Climatic DATA BelOngING TO THE LOCATIONS IN THE SAFFLOWER VeGETATION PERIOD OF 2016-2017 AND THE LONG-TERM AVERAGE (LTA) VALUES

\begin{tabular}{|c|c|c|c|c|c|c|c|c|c|c|c|c|c|c|c|c|c|c|c|c|}
\hline \multirow[t]{2}{*}{ Loc. } & \multirow[t]{2}{*}{ Month } & \multicolumn{3}{|c|}{$\begin{array}{c}\text { Average } \\
\text { temperature }\left({ }^{\circ} \mathrm{C}\right)\end{array}$} & \multicolumn{3}{|c|}{$\begin{array}{c}\text { Maximum } \\
\text { temperature }\left({ }^{\circ} \mathrm{C}\right)\end{array}$} & \multicolumn{3}{|c|}{$\begin{array}{c}\text { Minimum } \\
\text { temperature }\left({ }^{\circ} \mathrm{C}\right)\end{array}$} & \multirow[t]{2}{*}{$\begin{array}{l}\text { Humidity } \\
(\%)\end{array}$} & \multicolumn{3}{|c|}{ Precipitation $(\mathrm{mm})$} & \multicolumn{2}{|c|}{$\begin{array}{c}\text { Soil } \\
\text { temperature } \\
(5 \mathrm{~cm})\left({ }^{\circ} \mathrm{C}\right)\end{array}$} & \multicolumn{2}{|c|}{$\begin{array}{c}\text { Soil } \\
\text { temperature } \\
(10 \mathrm{~cm})\left({ }^{\circ} \mathrm{C}\right)\end{array}$} & \multicolumn{2}{|c|}{$\begin{array}{l}\text { Wind speed } \\
(\mathrm{km} / \mathrm{h})\end{array}$} \\
\hline & & LTA & 2016 & 2017 & LTA & 2016 & 2017 & LTA & 2016 & 2017 & & LTA & 2016 & 2017 & 2016 & 2017 & 2016 & 2017 & 2016 & 2017 \\
\hline \multirow{8}{*}{ 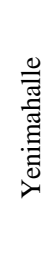 } & March & 4.9 & 8.0 & 8.1 & 21.4 & 23.4 & 19.9 & -5.9 & -2.4 & -1.5 & 60.2 & 36.7 & 78.5 & 46.1 & 9.5 & 9.6 & 9.6 & 9.6 & 2.2 & 2.3 \\
\hline & April & 9.4 & 14.3 & 11.0 & 25.7 & 28.1 & 27.2 & -0.8 & 0.5 & -1.0 & 50.6 & 46.7 & 17.2 & 19.8 & 17.1 & 13.7 & 16.9 & 13.7 & 2.2 & 2.5 \\
\hline & May & 15.5 & 15.1 & 15.8 & 29.3 & 29.3 & 29.2 & 4.1 & 5.9 & 5.0 & 55.9 & 49.9 & 55.7 & 47.4 & 19.3 & 19.9 & 19.1 & 19.8 & 2.1 & 2.5 \\
\hline & June & 19.9 & 22.0 & 20.4 & 33.6 & 36.9 & 35.8 & 8.1 & 9.2 & 9.0 & 58.0 & 34.2 & 9.7 & 47.4 & 27.4 & 24.1 & 27.0 & 23.8 & 2.8 & 1.3 \\
\hline & July & 24.9 & 25.0 & 25.6 & 36.2 & 37.1 & 38.3 & 11.4 & 12.7 & 14.2 & 38.1 & 14.3 & 0.0 & 0.0 & 31.9 & 30.0 & 31.2 & 29.8 & 3.1 & 1.6 \\
\hline & August & 22.5 & 25.3 & 24.7 & 35.8 & 36.6 & 37.8 & 11.5 & 13.3 & 13.3 & 45.8 & 13.1 & 60.6 & 13.7 & 30.4 & 29.1 & 30.4 & 29.0 & 3.0 & 3.0 \\
\hline & September & 16.4 & 19.2 & 22.6 & 32.6 & 32.9 & 37.7 & 6.6 & 5.3 & 7.7 & 34.2 & 17.5 & 22.5 & 3.5 & 23.5 & 26.0 & 23.9 & 25.9 & 2.4 & 2.3 \\
\hline & October & 13.8 & 13.8 & 12.6 & 27.6 & 28.1 & 23.7 & 1.1 & 1.7 & 3.2 & 56.3 & 31.8 & 2.9 & 19.2 & 17.8 & 14.3 & 18.2 & 14.9 & 2.2 & 1.0 \\
\hline \multirow{8}{*}{$\begin{array}{l}\vec{\Xi} \\
\overline{0} \\
0\end{array}$} & March & 4.9 & 7.6 & 6.1 & 22.5 & 25.9 & 19.8 & -7.6 & -3.8 & -3.3 & 68.3 & 52.3 & 48.8 & 30.6 & 9.0 & 8.2 & 9.0 & 8.3 & 1.4 & 1.5 \\
\hline & April & 9.9 & 12.6 & 8.1 & 26.1 & 30.4 & 27.1 & -2.0 & -0.8 & -3.3 & 66.4 & 50.5 & 46.6 & 62.2 & 15.0 & 11.4 & 14.9 & 11.4 & 1.4 & 1.5 \\
\hline & May & 14.1 & 13.9 & 12.8 & 29.7 & 28.7 & 30.3 & 1.7 & 3.6 & 4.2 & 74.5 & 56.9 & 82.3 & 68.4 & 17.1 & 15.7 & 17.0 & 15.8 & 1.4 & 1.4 \\
\hline & June & 17.7 & 19.9 & 17.4 & 32.7 & 34.7 & 32.9 & 5.6 & 7.2 & 6.9 & 73.4 & 51.2 & 47.1 & 56.2 & 23.0 & 21.6 & 22.9 & 21.5 & 1.6 & 1.5 \\
\hline & July & 20.2 & 20.5 & 20.7 & 34.5 & 36.5 & 37.5 & 8.5 & 8.3 & 10.5 & 64.1 & 32.8 & 0.0 & 7.0 & 25.5 & 26.5 & 25.4 & 26.4 & 1.6 & 1.6 \\
\hline & August & 20.1 & 20.5 & 20.2 & 34.5 & 35.0 & 33.2 & 8.7 & 8.0 & 7.4 & 64.8 & 26.0 & 20.9 & 33.8 & 25.7 & 27.5 & 25.7 & 27.2 & 1.4 & 1.7 \\
\hline & September & 16.3 & 15.4 & 17.4 & 32.4 & 31.1 & 36.1 & 4.5 & 3.8 & 4.5 & 59.1 & 24.4 & 35.8 & 4.2 & 21.6 & 23.2 & 21.7 & 23.1 & 1.4 & 1.3 \\
\hline & October & 12.0 & 10.4 & 9.9 & 28.2 & 26.3 & 23.3 & 0.3 & -0.2 & 0.9 & 74.3 & 46.8 & 15.6 & 84.6 & 15.1 & 12.9 & 15.2 & 13.1 & 1.2 & 1.2 \\
\hline \multirow{8}{*}{$\begin{array}{l}\overline{5} \\
\stackrel{5}{0} \\
\vdots 0 \\
0\end{array}$} & March & 4.7 & 5.9 & 5.2 & 20.4 & 22.3 & 17.7 & -7.7 & -5.7 & -4.4 & 62.1 & 16.3 & 67.0 & 31.4 & 6.2 & 5.6 & 6.7 & 5.8 & 3.0 & 3.1 \\
\hline & April & 9.5 & 11.9 & 8.0 & 23.6 & 27.2 & 23.2 & -2.2 & -1.3 & -3.2 & 54.4 & 12.8 & 11.9 & 16.8 & 12.7 & 9.1 & 12.5 & 9.2 & 3.1 & 3.1 \\
\hline & May & 14.3 & 12.7 & 13.0 & 27.4 & 26.9 & 27.4 & 2.6 & 4.0 & 3.6 & 56.6 & 45.3 & 58.0 & 27.6 & 15.7 & 14.7 & 15.6 & 14.6 & 2.8 & 3.2 \\
\hline & June & 22.8 & 19.0 & 17.6 & 35.8 & 31.8 & 33.7 & 9.8 & 5.7 & 5.7 & 57.3 & 1.2 & 8.4 & 27.4 & 21.9 & 20.7 & 21.3 & 19.9 & 2.7 & 2.6 \\
\hline & July & 22.6 & 22.2 & 22.8 & 34.9 & 35.9 & 35.4 & 10.1 & 9.7 & 10.9 & 42.0 & 15.5 & 1.8 & 0.2 & 25.7 & 26.1 & 25.2 & 25.5 & 2.9 & 2.9 \\
\hline & August & 17.7 & 22.5 & 22.1 & 31.9 & 34.0 & 34.2 & 4.8 & 10.2 & 10.2 & 48.2 & 16.2 & 24.3 & 0.0 & 25.1 & 24.7 & 25.1 & 24.4 & 2.7 & 2.6 \\
\hline & September & 18.6 & 16.3 & 20.0 & 31.8 & 30.2 & 35.1 & 6.7 & 1.9 & 4.4 & 39.2 & 13.4 & 53.5 & 30.2 & 18.1 & 21.3 & 19.1 & 21.3 & 2.5 & 2.5 \\
\hline & October & 11.1 & 11.4 & 10.3 & 25.2 & 25.9 & 21.1 & 0.1 & 0.0 & 0.5 & 56.7 & 7.0 & 7.7 & 9.8 & 12.7 & 12.1 & 13.9 & 13.1 & 2.4 & 2.5 \\
\hline
\end{tabular}

TABLE 3: SOME CHEMICAL AND PHySICAL PROPERTIES OF SOIL SAMPLES WERE TAKEN FROM 0-20 AND 20-40 CM DEPTHS OF THE TRIAL FIELDS

\begin{tabular}{|c|c|c|c|c|c|c|c|c|}
\hline \multirow{2}{*}{$\begin{array}{l}\text { Deep } \\
(\mathrm{cm})\end{array}$} & \multirow[b]{2}{*}{ Texture } & \multirow[b]{2}{*}{ Water saturation (\%) } & \multirow{2}{*}{$\begin{array}{c}\text { Total } \\
\text { salt } \\
(\%)\end{array}$} & \multirow{2}{*}{$\begin{array}{l}\mathrm{pH} \\
(\%)\end{array}$} & \multirow{2}{*}{$\begin{array}{c}\mathrm{CaCO}_{3} \\
(\%)\end{array}$} & \multicolumn{2}{|c|}{ Nutrients Used for Plants $\left(\mathrm{kg} \mathrm{da}^{-1}\right)$} & \multirow[b]{2}{*}{ Organic Matter (\%) } \\
\hline & & & & & & Phosphorus $\left(\mathrm{P}_{2} \mathrm{O}_{5}\right)$ & Potassium $\left(\mathrm{K}_{2} \mathrm{O}\right)$ & \\
\hline & & & & & Ikizce & & & \\
\hline $0-20$ & Clay loam & 69.0 & 0.018 & 7.97 & 27.23 & 7.90 & 244.51 & 1.34 \\
\hline $20-40$ & Clay loam & 66.0 & 0.025 & 8.10 & 28.48 & 4.84 & 170.41 & 1.10 \\
\hline \multicolumn{2}{|c|}{ Mean } & 67.5 & 0.02 & 8.04 & $\begin{array}{c}27.86 \\
\text { Bolu }\end{array}$ & 6.37 & 207.46 & 1.22 \\
\hline $0-20$ & Clay & 84.0 & 0.041 & 7.30 & 3.71 & 54.52 & 286.32 & 2.36 \\
\hline $20-40$ & Clay & 84.0 & 0.049 & 7.23 & 4.52 & 63.26 & 348.99 & 2.87 \\
\hline \multicolumn{2}{|r|}{ Mean } & \multicolumn{6}{|c|}{ Yenimahalle } & 2.62 \\
\hline $0-20$ & Clay loam & 56.0 & 0.014 & 8.00 & 7.46 & 8.29 & 174.67 & 1.15 \\
\hline $20-40$ & Clay loam & 62.0 & 0.015 & 7.97 & 7.02 & 9.11 & 187.75 & 1.36 \\
\hline & Mean & 59.00 & 0.01 & 7.99 & 7.24 & 8.70 & 181.21 & 1.26 \\
\hline
\end{tabular}

\section{RESUlT AND DISCUSSION}

Environment and genotype, which are sources of variation, and the effect of their interaction were found statistically significant at $1 \%$ probability level on seed yield and oil yield. (Table 4).

TABLE 4: ANALYSIS OF VARIANCE OF SEED YIELD (KG DA-1) AND OIL YIELD (KG DA-1) OF GENOTYPES IN THE ENVIRONMENTS

\begin{tabular}{cccc}
\hline \multirow{2}{*}{ Source } & \multirow{2}{*}{ DF } & Seed yield & Oil yield \\
\cline { 3 - 4 } & & MS & MS \\
\hline Enviroment (E) & 5 & $136582.00^{* *}$ & $13551.20^{* *}$ \\
Replication (E) & 12 & $719.88^{* *}$ & $117.53^{* * *}$ \\
Genotyp (G) & 19 & $5646.40^{* *}$ & $587.82^{* *}$ \\
G x E & 95 & $1951.20^{* *}$ & $199.64^{* *}$ \\
Error & 228 & 115.77 & 14.45 \\
Total & 359 & 2815.01 & 285.78 \\
Coefficient of Variation $(\mathrm{CV})$ & 10.15 & 10.94 \\
\hline
\end{tabular}

** Important at a probability level of $0.01(\mathrm{p}<0.01)$; DF: Degree of freedom; MS: Mean squares.

When the environmental averages of the genotypes are evaluated, Dinçer and Remzibey-05 varieties are included in the same statistical group with the highest seed yield values (134.49 $\mathrm{kg} \mathrm{da}^{-1}$ and $126.46 \mathrm{~kg} \mathrm{da}^{-1}$ respectively). GenotypeNo. $133\left(57.32 \mathrm{~kg} \mathrm{da}^{-1}\right)$ has the lowest seed yield value.
In terms of oil yield, when the genotypes were evaluated together with the averages of all locations, it was seen that genotypes 8 and 155 were involved in the same statistical group and showed the highest oil yield value $\left(42.32 \mathrm{~kg} \mathrm{da}^{-1}\right.$, $44.24 \mathrm{~kg} \mathrm{da}^{-1}$ respectively). Genotype-133 had the lowest oil yield $\left(19.01 \mathrm{~kg} \mathrm{da}^{-1}\right)$.

When environments are compared in terms of seed yield averages, it is seen that the 2017 İkizce location has the highest seed yield average $\left(182.53 \mathrm{~kg} \mathrm{da}^{-1}\right)$ whereas the 2016 Bolu location has the lowest seed yield value $\left(52.83 \mathrm{~kg} \mathrm{da}^{-1}\right)$.

When researches conducted on safflower seed yield are examined, the results have been reported in a wide range between $27.98 \mathrm{~kg} \mathrm{da}^{-1}$ and $342.52 \mathrm{~kg} \mathrm{da}^{-1}$ [20], [21]. These values show that the safflower plant has a large variation in seed yield due to variety, environment and applications.

In experiments conducted in multiple environments, genotype (G) and genotype $x$ environment interaction (GE) are shown together on the polygon chart (Fig. 1 and Fig. 2). The polygon consists of lines drawn between the genotypes farthest from the origin. All other genotypes remain within the polygon. When the seed yield is examined (Fig. 1), the lines drawn perpendicular to each side of the polygon create 7 regions in the biplot. 4 of these regions include trial 
environments. It means that the genotypes at the peaks of the polygon in the regions formed outperform all the genotypes in all of the environments in that region. In the 1st region, Genotype-114 has a higher seed yield in E3 (İkizce-2016) than genotypes $163,143,10$, and 117 ; In the second region, it is seen that Dinçer variety has higher seed yield in E4 (İkizce-2017) and E5 (Yenimahalle-2016) environments. In the third region, the Remzibey-05 variety had the highest seed yield among genotypes in E2 (Bolu-2017). In the fourth region, Genotype-83 has reached the highest seed yield in E1 (Bolu-2016) and E6 (Yenimahalle-2017).

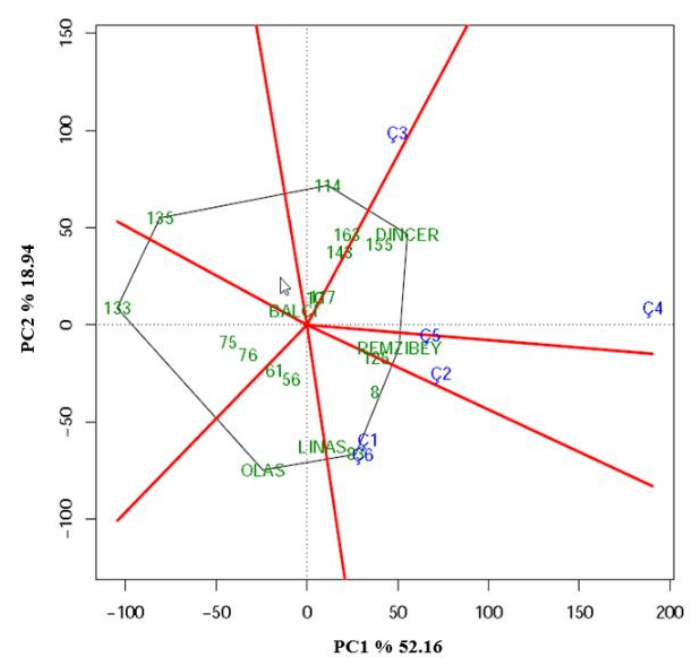

Fig. 1. GGE-biplot polygon graphic for safflower genotypes and environments in seed yield.

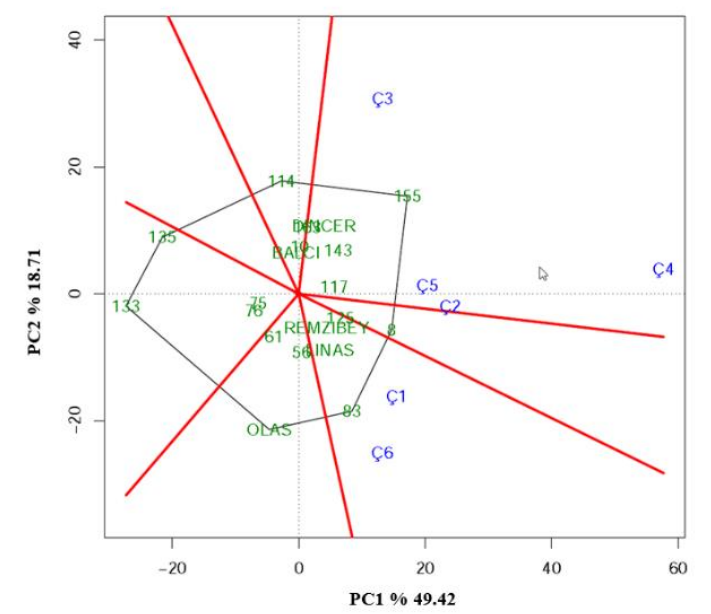

Fig. 2. GGE-biplot polygon chart for safflower genotypes in oil yield and environments.

7 regions were formed in the polygon for oil yield. Only two regions covered all six trial environments (Fig. 2). Genotype-155 has the highest yield in E2 (Bolu-2017), E3 (İkizce-2016), E4 (İkizce-2017) and E5 (Yenimahalle-2016) environments in the same region. In the other region, where E1 (Bolu-2016) and E6 (Yenimahalle-2017) are located, Genotype-83 had the highest oil yield.

The biplot graph, based on the comparison of genotypes in terms of seed yield, (Fig. 3) showed that Remzibey-05 cultivar, Genotype-125, and Genotype- 8 were located closest to the ideal genotype center. It was seen that the environment closest to the ideal environment in terms of seed yield was E4 (İkizce-2017), followed by E2 (Bolu-2017) and E5
(Yenimahalle-2016). Genotypes, between the Genotype-114 and the Dinçer variety (on the line cutting the center of the circles), had above average seed yield and the most stable genotypes among them (those who have the shortest vertical distance to this line) were determined as Remzibey-05 variety and Genotype-125 (Fig. 3).

It is seen that Genotype-8, which is closest to the ideal genotype center in terms of oil yield, is located, followed by Genotype-117 and Remzibey-05 varieties (Fig. 4). The ideal environment was E5 (Yenimahalle-2016). Genotypes, that between Genotype-63 and Genotype-155, had above-average oil yields. Genotypes 117 to 125 were the most stable genotypes in oil yield (Fig. 4).

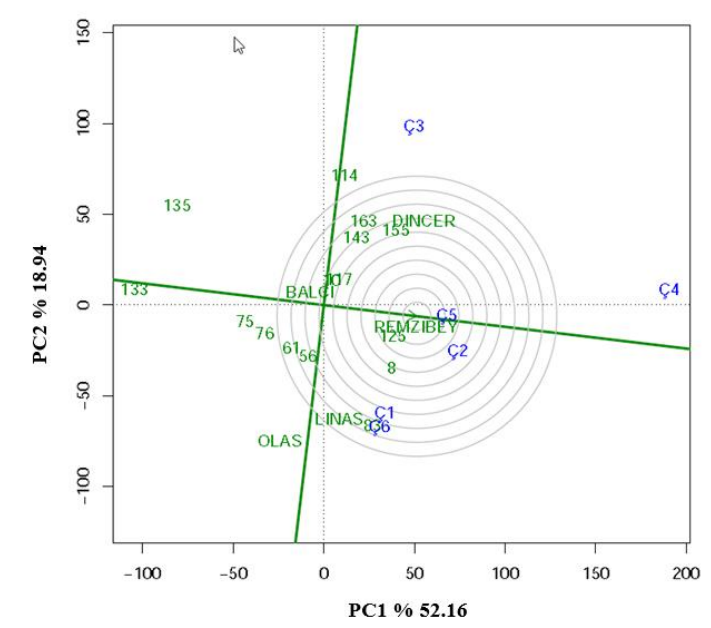

Fig. 3. GGE-biplot showing the ranking of 20 safflower genotypes based on seed yield and stability performance over six environments.

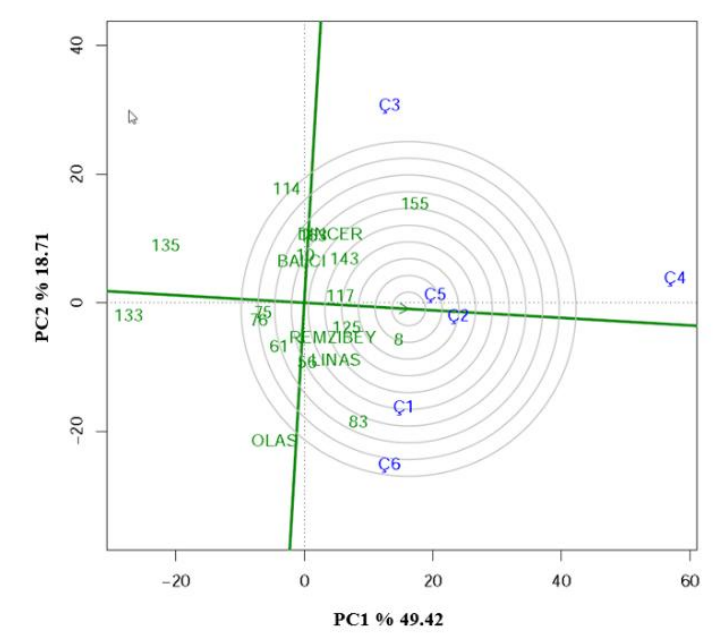

Fig. 4. GGE-biplot showing the ranking of 15 safflower genotypes based on oil yield and stability performance over six environments.

Stability parameters in terms of seed yield were shown (Table 5). Since the lowest CV values indicate the most stable genotypes [22], the most stable genotypes were detected as, Linas, Olas, and Balcı varieties. The Genotype-114 has the lowest stability. When the genotypes are compared in terms of the "a" value since the highest "a" value indicates the most stable genotypes Linas was determined as the most stable one followed by the Olas variety and Genotype-10. Genotype-114 has the lowest stability in terms of "a" value (Table 2).

The regression coefficient $\left(b_{i}\right)$ of a stable genotype is required to close to 1 [9], [23]. According to this parameter, the most stable genotypes are Genotype-83, Genotype-76 and 
Genotype-56, respectively, and it is seen that Linas variety has the lowest stability value.

The genotypes were also evaluated in terms of deviations mean squares $\left(S^{2} d_{i}\right)$. If the Deviations mean squares $\left(S^{2} d_{i}\right)$ value is equal to or closest to zero, it indicates the most stable genotype [23], [24]. Compared to the other genotypes, the most stable genotype is Genotype-143 with the lowest $S^{2} d_{i}$ value, followed by Balc1 variety and Genotype- 163 . According to this parameter, it is seen that Genotype-135 has the lowest stability.

The high coefficient of determination $\left(\mathrm{R}_{\mathrm{i}}{ }^{2}\right)$ (close to 1 ) means high stability [9]. Accordingly, Genotype-143 was the most stable genotype in terms of $\mathrm{R}_{\mathrm{i}}{ }^{2}$ value as it was the closest genotype to 1 . This is followed by Genotype-163 and variety Remzibey-05. The Linas variety has the lowest stability according to seed yield.

The value closest to 0 is accepted as the most stable in the evaluation of the stability variance $\left(\sigma_{\mathrm{i}}^{2}\right)$, which was developed by Shukla (1972) [19] and based on the calculation of the variance of the genotype overall environments.
According to this, in terms of $\sigma_{\mathrm{i}}^{2}$ value, Balc1 variety is the most stable genotype, Genotypes 56 and 61 follow this. Linas variety has the lowest stability for seed yield.

When the stability of genotypes in terms of ecovalance value $\left(\mathrm{W}_{\mathrm{i}}\right)$ is examined, according to Wricke (1962) [25], the smallest ecovalance value shows the highest stability. Among the analyzed genotypes, the most stable genotype in terms of this parameter is seen as the Balc1 variety. Genotype-56 and Genotype-61 follow this. Linas variety shows the lowest stability in terms of this parameter.

A stability index $\left(\mathrm{P}_{\mathrm{i}}\right)$, which is a stability indicator based on a comparison of the productivity of genotypes in different environments, was proposed by Lin and Binns (1988). The genotype with the best performance and the lowest $\mathrm{P}_{i}$ value is considered to be the best genotype [26]. Accordingly, Dinçer variety is seen as the most stable genotype in terms of $\mathrm{P}_{i}$ value. This is followed by Genotype- 155 and variety Remzibey-05. According to this parameter, it is seen that the Genotype-133 has the lowest stability.

TABLE 5. SOME PARAMETRIC AND NONPARAMETRIC STABILITY VALUES OF SEED YIELD

\begin{tabular}{|c|c|c|c|c|c|c|c|c|c|c|c|}
\hline Genotypes & $\bar{x}$ & $\mathrm{CV}(\%)$ & $\mathrm{a}$ & $b_{i}$ & $\mathrm{~S}^{2} \mathrm{di}$ & $\mathrm{R}_{\mathrm{i}}^{2}$ & $\sigma \mathrm{i}^{2}$ & $\mathrm{~W}_{\mathrm{i}}$ & $\mathrm{P}_{\mathrm{i}}$ & $\mathrm{S}_{\mathrm{i}}^{(1)}$ & $\mathrm{S}_{\mathrm{i}}^{2}$ \\
\hline 8 & 119.862 & 51.303 & -3.385 & 1.163 & 839.775 & 0.814 & 811.794 & 3815.671 & 1181.174 & 3.20 & 27.6 \\
\hline 10 & 110.116 & 43.457 & 18.719 & 0.862 & 707.338 & 0.739 & 674.774 & 3199.083 & 1494.625 & 2.73 & 30.2 \\
\hline 56 & 100.663 & 45.591 & 1.809 & 0.933 & 118.145 & 0.941 & 114.599 & 678.296 & 1838.500 & 1.87 & 16.8 \\
\hline 61 & 97.831 & 45.855 & 3.734 & 0.888 & 233.723 & 0.892 & 237.707 & 1232.281 & 2047.106 & 1.60 & 20.6 \\
\hline 75 & 90.965 & 43.089 & 12.930 & 0.736 & 339.207 & 0.803 & 475.581 & 2302.717 & 2583.429 & 1.33 & 18.8 \\
\hline 76 & 94.123 & 54.324 & -5.786 & 0.943 & 700.589 & 0.774 & 629.210 & 2994.046 & 2534.062 & 1.80 & 39.8 \\
\hline 83 & 116.849 & 47.920 & 9.884 & 1.009 & 981.772 & 0.740 & 871.074 & 4082.435 & 1382.624 & 2.07 & 42.2 \\
\hline 114 & 98.401 & 72.595 & -51.546 & 1.415 & 643.423 & 0.893 & 1005.506 & 4687.376 & 2053.741 & 1.67 & 30.8 \\
\hline 117 & 111.783 & 51.991 & -13.663 & 1.184 & 196.757 & 0.944 & 258.381 & 1325.315 & 1266.235 & 2.00 & 16.0 \\
\hline 125 & 115.876 & 50.865 & -3.006 & 1.122 & 723.512 & 0.825 & 678.768 & 3217.054 & 1209.307 & 2.80 & 35.4 \\
\hline 133 & 57.318 & 60.048 & -8.560 & 0.622 & 342.660 & 0.743 & 664.864 & 3154.489 & 5521.945 & 0.13 & 0.80 \\
\hline 135 & 74.372 & 59.314 & 5.097 & 0.654 & 1178.025 & 0.500 & 1348.674 & 6231.634 & 4073.820 & 1.93 & 22.6 \\
\hline 143 & 111.356 & 57.597 & -29.931 & 1.333 & 46.025 & 0.984 & 319.844 & 1601.899 & 1248.248 & 1.33 & 18.2 \\
\hline 155 & 121.106 & 53.205 & -16.450 & 1.298 & 356.930 & 0.924 & 540.081 & 2592.963 & 816.756 & 1.67 & 24.6 \\
\hline 163 & 110.409 & 58.899 & -31.893 & 1.343 & 116.991 & 0.971 & 399.352 & 1959.683 & 1273.201 & 1.47 & $19 . .0$ \\
\hline BALCI & 107.543 & 39.191 & 16.013 & 0.864 & 59.356 & 0.956 & 97.939 & 603.327 & 1397.426 & 1.27 & 10.0 \\
\hline DİNÇER & 134.488 & 47.795 & -2.762 & 1.295 & 353.138 & 0.924 & 532.362 & 2558.227 & 394.981 & 0.87 & 12.0 \\
\hline LİNAS & 115.971 & 26.601 & 74.482 & 0.392 & 714.803 & 0.367 & 1569.993 & 7227.567 & 1545.021 & 2.93 & 60.2 \\
\hline OLAS & 104.052 & 36.686 & 43.777 & 0.569 & 862.294 & 0.505 & 1234.982 & 5720.017 & 2181.687 & 2.07 & 51.2 \\
\hline R.BEY & 126.458 & 53.124 & -19.464 & 1.377 & 208.240 & 0.956 & 542.539 & 2604.024 & 824.825 & 1.93 & 19.2 \\
\hline
\end{tabular}

$\overline{\mathrm{X}}$ : mean seed yield $\left(\mathrm{kg} \mathrm{da}^{-1}\right), \mathrm{CV}$ : coefficient of variability, ai: environmental effects, bi: regression coefficient, $\mathrm{S}^{2}{ }_{\mathrm{di}}$ : deviations mean squares, $\mathrm{R}_{\mathrm{i}}{ }^{2}$ : coefficients of determination, $\sigma \mathrm{i}^{2}$ : stability variance, $\mathrm{W}_{\mathrm{i}}$ : ecovalance, $\mathrm{P}_{\mathrm{i}}$ : superiority index, $\mathrm{S}_{\mathrm{i}}{ }^{(1)}$ and $\mathrm{S}_{\mathrm{i}}^{(2)}$ : nonparametric measures of stability [18].

$S_{i}$ (1) and $S_{i}(2)$, non-parametric stability measures, are calculated according to the level of change in the order of genotypes in the environment. Genotypes with low-rank values in the environment are considered to be more stable [26], [27]. Accordingly, the most stable genotypes in terms of $S_{i}$ (1) value were 133, Dinçer and Balcı genotypes, respectively, while Genotype-133, Balcı and Dinçer were determined according to $\mathrm{S}_{\mathrm{i}}(2)$ values.

According to the results of Spearman's rank correlation coefficient between the statistics of parametric and nonparametric stability and average seed yield calculated using the rank value of each stability parameter with each other [27], average seed yield in the environment has a significant positive correlation with $\mathrm{Pi}(\mathrm{p}<0.01)$ while no significant correlation was found with other stability factors. While there was a correlation $(p<0.01)$, there was no significant correlation with other stability factors. While there is a positive correlation $(\mathrm{p}<0.01)$ between the CV and the "a" value, it is seen that there was a negative correlation between the "a" value and $r_{i}^{2}(p<0.01)$. Additionally, the $S^{2} d_{i}$ value had a positive and significant correlation with $\mathrm{r}_{\mathrm{i}}^{2}, \sigma_{\mathrm{i}}^{2}, \mathrm{~W}_{\mathrm{i}}, \mathrm{P}_{\mathrm{i}}$,
$S_{i}(1), S_{i}(2)$ values, and $r_{i}^{2}$ value with $\sigma_{i}^{2}, W_{i}, P_{i}, S_{i}(1), S_{i}(2)$ values. The value of $\sigma_{\mathrm{i}}^{2}$ and $\mathrm{W}_{\mathrm{i}}$ had a positive and significant correlation with $S_{i}(1)$ and $S_{i}(2)$, and the value of $S_{i}(1)$ with $S_{\mathrm{i}}(2)$ (Table 6).

In terms of seed yield, Dinçer and Remzibey-05 varieties were included in the same group and had the highest yield value (134.49 $\mathrm{kg} \mathrm{da}^{-1}, 126.46 \mathrm{~kg} \mathrm{da}^{-1}$, respectively) based on location averages, whereas the lowest yield value belongs to the Genotype-133 (57.32 $\left.\mathrm{kg} \mathrm{da}^{-1}\right)$. When the environments were compared in terms of the average yield of genotypes, it was observed that 5 different groups were formed statistically. The location of İkizce in 2017 (E4) had the highest yield value, whereas the Bolu location in 2016 (E1) showed the lowest yield value.

Changing the performance sequences of breeding lines in different environments is an indicator of the importance of genotype $\mathrm{x}$ environment interaction (GEI). Type 1 stability concept suggested by Becker Leon (1988) [9] expressed that the genotype does not show variation among to environments. With this concept of stability, genotypes that respond well to good environments cannot be determined, so it is not useful 
for farmer's cultivar selection. Therefore, type 2 stability, which is indicated by Lin et. al. (1986) [10], is more useful since it also takes into account the yield potential. A genotype with type 2 stability is stable if its response to the environment parallels all genotypes. Sabaghria et al (2008) [28] and Mohammadi \& Amri (2008) [29] reported that $\mathrm{P}_{\mathrm{i}^{-}}$ based selection is important in terms of efficiency. This approach is available in many studies for various crops, such as safflower [30]-[32], soybean [33]-[36], sugar beet [26], wheat [37], cowpea [38], barley [24] and turmeric [39] in multiple locations.

In terms of yield, Genotype-155 may be selected in a $\mathrm{P}_{\mathrm{i}^{-}}$ based selection in Turkey conditions, however, Remzibey-05 variety and Genotype-125 were ideal in a holistic sense. It has been determined that the ideal environment in terms of yield was E4 (İkizce-2017).

\begin{tabular}{|c|c|c|c|c|c|c|c|c|c|c|}
\hline & Mean & $\mathrm{CV}(\%)$ & $\mathbf{a}_{\mathbf{i}}$ & $\mathbf{b}_{\mathbf{i}}$ & $\mathbf{S}_{\mathrm{di}}^{\mathbf{2}}$ & $\mathbf{r}_{i}^{2}$ & $\sigma_{i}^{2}$ & $\mathbf{W}_{\mathbf{i}}$ & $\mathbf{P}_{\mathrm{i}}$ & $\mathbf{S}_{\mathbf{i}^{(1)}}$ \\
\hline $\mathrm{CV}(\%)$ & 0.162 & & & & & & & & & \\
\hline $\mathbf{a}_{\mathbf{i}}$ & -0.143 & $0.836 * *$ & & & & & & & & \\
\hline $\mathbf{b}_{\mathbf{i}}$ & 0.009 & 0.211 & 0.153 & & & & & & & \\
\hline $\mathbf{S}_{\mathrm{di}}^{2}$ & -0.032 & -0.075 & -0.414 & 0.053 & & & & & & \\
\hline $\mathbf{r}_{i}^{2}$ & 0.311 & -0.262 & $-0.657 * *$ & 0.108 & $0.842 * *$ & & & & & \\
\hline$\sigma_{i}^{2}$ & -0.032 & 0.081 & -0.236 & 0.430 & $0.884 * *$ & $0.767 * *$ & & & & \\
\hline $\mathbf{W}_{\mathbf{i}}$ & -0.032 & 0.081 & -0.236 & 0.430 & $0.884 * *$ & $0.767 * *$ & 1.000 & & & \\
\hline $\mathbf{P}_{\mathrm{i}}$ & $0.932 * *$ & 0.023 & -0.331 & 0.123 & 0.189* & $0.559 * *$ & 0.224 & 0.224 & & \\
\hline $\mathbf{S}_{\mathrm{i}}^{(\mathbf{1})}$ & -0.347 & -0.283 & -0.302 & -0.066 & $0.624 * *$ & $0.447 *$ & $0.571 * *$ & $0.571 * *$ & -0.17 & \\
\hline $\mathbf{S}_{\mathrm{i}}^{(2)}$ & -0.126 & -0.176 & -0.286 & 0.039 & $0.749 * *$ & $0.612 * *$ & $0.746 * *$ & $0.746 * *$ & 0.095 & $0.725 * *$ \\
\hline
\end{tabular}

$* \% 5, * * \% 1$ levels is important. The critical value of the correlation is 0.447 and 0.570 for $\mathrm{P}<0.05$ and $\mathrm{P}<0.01$, respectively. Values that differ from 0.00 are bold.

\section{REFERENCES}

[1] M. J. Mahasi, R. S. Pathak, F. N. Wachira, T. C. Riungu, M. G. Kinyua, and J. K. Waweru, "Genotype by environment (GxE) interaction and stability in safflower (Carthamus tinctorious L.)," Asian J. Plant Sci., vol. 5, no. 6, pp. 1017-1021, 2006, doi: 10.3923/ajps.2006.1017.1021.

[2] A. Ashri and P. F. Knowles, "Cytogenetics of Safflower (Carthamus L.) Species and Their Hybrids 1 ," Agron. J., vol. 52, no. 1, pp. 11-17, 1960, doi: 10.2134/agronj1960.00021962005200010004x.

[3] P. F. Knowles, "Centers of plant diversity and conservation of crop germ plasm: Safflower,” Econ. Bot., vol. 23, no. 4, pp. 324-329, 1969, doi: 10.1007/BF02860678.

[4] Y. Arslan and B. Tarikahya Hacioğlu, "Seed fatty acid compositions and chemotaxonomy of wild safflower (Carthamus L., asteraceae) species in Turkey," Turkish J. Agric. For., vol. 42, no. 1, pp. 45-54, 2018, doi: 10.3906/tar-1708-68.

[5] J. R. Smith, Safflower, Champaign,. AOCS Press, 1996.

[6] H. Dajue, L.; Mündel, Safflower, Carthamus tinctorius L. (Vol. 7) 1996. Bioversity International.

[7] V. L. Bradley, R. L. Guenthner, R. C. Johnson, and R. M. Hannan, "Evaluation of Safflower Germplasm for Ornamental Use," no. Table 1, pp. 433-435, 1999.

[8] M. M. Karimkhani, R. Shaddel, M. H. H. Khodaparast, M. Vazirian, and S. Piri-Gheshlaghi, "Antioxidant and antibacterial activity of safflower (Carthamus tinctorius L.) extract from four different cultivars," Qual. Assur. Saf. Crop. Foods, vol. 8, no. 4, pp. 565-574, 2016, doi: 10.3920/QAS2015.0676.

[9] H. C. Becker and J. Leon, "Stability analysis in plant breeding," Plant Breed., vol. 101, pp. 1-23, 1988, doi: 10.1111/j.14390523.1988.tb00261.x.

[10] C. S. Lin, M. R. Binns, and L. P. Lefkovitch, "Stability Analysis: Where Do We Stand?," Crop Sci., 1986, doi: 10.2135/cropsci1986.0011183X002600050012x.

[11] H. C. Becker, "Correlations among some statistical measures of phenotypic stability," Euphytica, 1981, doi: 10.1007/BF00038812.

[12] Y. Arslan, "Farklı azot ve fosfor seviyelerinin kuru şartlarda yetiştirilen aspir (Carthamus tinctorius L.) bitkisinin verim ve verim özellikleri üzerine etkisi / Effect of different levels of nitrogen and phosphorus on the yield and yield component of safflower", Ankara Ün. Fen Bilimleri Enstitüsü, 2014.

[13] M. Bertrand and L. Brühl, "Comparison of Different Methods for the Determination of the Oil Content in Oilseeds," J. Am. Oil Chem. Soc., vol. 78, no. 1, pp. 95-102, 2001, doi: https://doi.org/10.1007/s11746001-0226-y.

[14] J. Mossé, "Nitrogen to Protein Conversion Factor for Ten Cereals and Six Legumes or Oilseeds. A Reappraisal of Its Definition and Determination. Variation According to Species and to Seed Protein Content," J. Agric. Food Chem., 1990, doi: 10.1021/jf00091a004.

[15] Asia Nosheen, Asghari Bano, "Effect of plant growth promoting rhizobacteria on root morphology of Safflower (Carthamus tinctorius L.)," African J. Biotechnol., vol. 10, no. 59, pp. 12639-12649, 2012, doi: 10.5897/ajb11.1647.
[16] Y. Kaya, M. Akçura, and S. Taner, "GGE-Biplot analysis of multienvironment yield trials in bread wheat," Turkish J. Agric. For., vol. 30, no. 5, pp. 325-337, 2006, doi: 10.3906/tar-0604-6.

[17] S. K. Tiiennarasu, "On Certain Non-Parametric Procedures For Studying Genotype - Environment Interactions. And Yield Stability," Indian Agricultural Statistics Research Institute Post- Graduate School, 1995.

[18] M. Huehn, "Nonparametric measures of phenotypic stability. Part 1 : Theory," 1990.

[19] G. K. Shukla, "Some statistical aspects of partitioning genotypeenvironmental components of variability," Heredity (Edinb)., vol. 29, no. 2, pp. 237-245, 1972, doi: 10.1038/hdy.1972.87.

[20] T. Polat, "Farklı Sıra Aralıkları Ve Azot Seviyelerinin Kuru Şartlarda Yetiştirilen Aspir (Carthamus Tinctorius L.) Bitkisinin Verim ve Verim Unsurları Üzerine Etkisi," 2007.

[21] N. Kunt, "Aspir (Carthamus tinctorius L.)'de Farklı Sıra Üzeri Mesafelerinin ve Yabancı Ot Mücadelesinin Verim ve Kalite Üzerine Etkisi," Selçuk Üniversitesi Fen Biilimleri Enstitüsü, 2012.

[22] T. R. Francis and L. W. Kannenberg, "Yield stability studies in shortseason maize. I. A descriptive method for grouping genotypes," Canadian Journal of Plant Science, 1978, 58.4: 10291034.

[23] Eberhart and W. A. Russell, “(1966) Stability Parameters for Comparing Varieties," no. 3, 1966.

[24] Z. Mut, "Comparison of stability statistics for yield in barley (Hordeum vulgare L.)," African J., vol. 9, no. 11, pp. 1610-1618, 2010, [Online]. Available:

http://www.academicjournals.org/Ajb/PDF/pdf2010/15Mar/Mut et al.pdf.

[25] M. Kang, "Modified rank-sum method for selecting high yielding, stable crop genotypes," Cereal Res. Commun, vol. 19, no. 3, pp. 361364, 1991.

[26] R. A. Rea, O. De Sousa-Vieira, A. Díaz Lucena, M. Ramón, and R. Briceño Cárdenas, "Genotype by environment interaction and yield stability in sugarcane," Rev. Fac. Nac. Agron., vol. 70, no. 2, pp. 8129 8138, 2017, doi: 10.15446/rfna.v70n2.61790.

[27] M. J. Moghaddam and S. S. Pourdad, "Comparison of parametric and non-parametric methods for analysing genotype $\times$ environment interactions in safflower (Carthamus tinctorius L.)," J. Agric. Sci., vol. 147, p. 601, 2009, doi: 10.1017/S0021859609990050.

[28] N. Sabaghnia, S. H. Sabaghpour, and H. Dehghani, "The use of an AMMI model and its parameters to analyse yield stability in multienvironment trials," J. Agric. Sci., vol. 146, no. 5, pp. 571-581, 2008 , doi: $10.1017 / \mathrm{S} 0021859608007831$.

[29] R. Mohammadi and A. Amri, "Comparison of parametric and nonparametric methods for selecting stable and adapted durum wheat genotypes in variable environments," Euphytica, vol. 159, no. 3, pp. 419-432, 2008, doi: 10.1007/s10681-007-9600-6.

[30] S. Sardouie-Nasab, S. Zareie, A. Saeed Pour, and G. MohammadiNejad, "Genotype $\times$ environment interactions for high seed yield and stability in safflower (Carthamus tinctorius L.) genotypes from Iran,' Int. J. Agric. Res. Rev., vol. 3, no. 4, pp. 838-843, 2013, [Online]. Available: http://www.ecisi.com. 
[31] M. E. Torbaghan, A. Mirzaee and M. J. Moghaddam, "Analysis of genotype $\times$ environment interaction for seed yield in spineless safflower (Carthamus tinctorius L.) genotypes.", Crop Breeding Journal, 2014, vol. 4, no. 1, pp. 47-56.

[32] M. Hamza, "Stability analysis of seed and oil yields in safflower genotypes under divergent environments in Egypt," Egypt. J. Appl. Sci, 2014, no. 29, pp. 743-757.

[33] F. Gurmu, H. Mohammed, and G. Alemaw, "Genotype x environment interactions and stability of soybean for grain yield and nutrition quality," African Crop Sci. J., vol. 17, no. 2, 2010, doi: 10.4314/acsj.v17i2.54202.

[34] D. A. Silveira, L. F. Pricinotto, M. Nardino, C. A. Bahry, C. E. C. Prete, and L. Cruz, "Determination of the adaptability and stability of soybean cultivars in different locations and at different sowing times in Paraná state using the AMMI and Eberhart and Russel methods," Semin. Agrar., vol. 37, no. 6, pp. 3973-3982, 2016, doi: 10.5433/16790359.2016v37n6p3973.

[35] M. Kocaturk et al., "GGE biplot analysis of genotype $\times$ environment interaction in soybean grown as a second crop," Turkish J. F. Crop., vol. 24, no. 2, pp. 145-154, 2019, doi: 10.17557/tjfc.615175.

[36] A. T. Goksoy, M. Sincik, M. Erdogmus, M. Ergin, S. Aytac, G. Gumuscu, O. Gunduz, R. Keles, G. Bayram and E. Senyigit, "The parametric and non-parametric stability analyses for interpreting genotype by environment interaction of some soybean genotypes," Turkish J. F. Crop., vol. 24, no. 1, pp. 28-38, 2019, doi: $10.17557 /$ tjfc. 562637 .

[37] E. Farshadfar, N. Mahmodi and A. Yaghotipoor, "AMMI stability value and simultaneous estimation of yield and yield stability in bread wheat (Triticum aestivum L.)," Aust. J. Crop Sci., vol. 5, no. 13, pp. 1837-1844, 2011.

[38] B. D. Adewale, C. Okonji, A. A. Oyekanmi, D. A. C. Akintobi and C. O. Aremu, "Genotypic variability and stability of some grain yield components of Cowpea," African J. Agric. Res., vol. 5, no. 9, pp. 874 880, 2010, doi: 10.5897/AJAR09.481.

[39] M. Anandaraj, D. Prasath, K. Kandiannan, T. J. Zachariah, V. Srinivasan, A. K. Jka, B. K. Singh, A. K. Singh, V. P. Pandey, S. P. Singh, N. Shoba, J. C. Cana, K. R. Kumar and K. U. Maheswari, "Genotype by environment interaction effects on yield and curcumin in turmeric (Curcuma longa L.)," Ind. Crops Prod., vol. 53, pp. 358-364, 2014, doi: 10.1016/j.indcrop.2014.01.005.

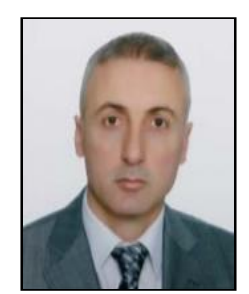

İlhan Subaşı, a citizen of Turkey, is an assistant professor at Abant İzzet Baysal University Turkey. $\mathrm{He}$ did Doctorate and Master of Science in Agronomy at the University of Ankara. His primary interest is on oilseed agronomy and breeding with main on quality.

Dr İlhan Subaşı is a member of Oil Science and Technology Association (YABITED).

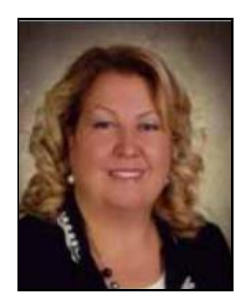

Dilek Başalma, a citizen of Turkey, is a professor at Ankara University Turkey. She did Doctorate and Master of Science in Agronomy at the University of Ankara. Her main interest is on oilseed agronomy and breeding.

Prof. Dr. Dilek Başalma is a member of Society of Fields Crop Science. 